

\title{
Report of the Canadian Arctic Expedition, 1913-18.
}

\author{
VOLUME VII: CRUSTACEA
}

Part A: DECAPOD CRUSTACEANS. By Mary J. Rathbun....... (Issued August 18, 1919). Part B: SCHIZOPOD CRUSTACEANS. By Waldo L. Schmitt. (Issued September 22, 1919). Part C: CUMACEA. By W. T. Calman........................ (In press). Part D; ISOPODA. By Miss P. L. Boone..................... (In press). Part E: AMPHIPODA. By Clarence R. Shoemaker............ (Issued September 7, 1920). Part F: PYCNOGONIDA. Lieon J. Cole........................ (In press). Part G: EUPHYLLOPODA. 'By F. Johansen.................... In preparation). Part H: CLADOCERA. By Chancey Juday ................... (Issued June 23, 1920). Part I: OSTRACODA. By R. W. Sharpe................... In preparation). Part J: FRESHWATER COPEPODA. - By C. Dwight Marsh......(Issued A pril 21, 1920). Part K: MARINE COPEPODA. By A. Willey............... (Issued June 25, 1920). Part L: PARASITIC COPEPODA. By Charles B. Wilson........ (Issued August 6, 1920). Part M: CIRRIPEDIA. By H. A. Pilsbry.................... In preparation). 


\section{R E P O R T}

OF THE

\section{CANADIAN ARCTIC EXPEDITION 1913-18}

VOLUME VII: CRUSTACEA

PART C: CUMACEA

By W. T. CALMAN

SOUTHERN PARTY-1913-16

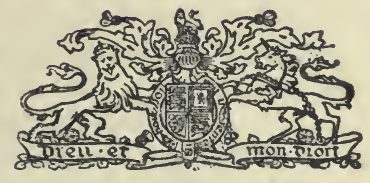

OTTAWA

THOMAS MULVEY

PRINTER TO THE KING'S MOST EXCELLENT MAJESTY 



\title{
Gumacea of the Canadian Arctic Expedition 1913-1918. ${ }^{1}$
}

\author{
By W. T. Calman, D. Sc.
}

\section{Department of Zoology, British Museum (Natural History).}

The collection of these Crustacea obtained by Mr. F. Johansen during the Canadian Arctic Expedition although small is of considerable interest as coming from a region hitherto quite unexplored in respect of this as of most other groups of marine animals.

The full synonymy of the species mentioned will be found in Stebbing's revision of the Cumacea (Das Tierreich, Lief. 39, 1913). Some important records of distribution have since been published by Hansen (Danish IngolfExpedition, Vol. III, 6 (Malacostraca IV.) 1920. Most of the American records are quoted in my paper on the Cumacea of the U.S. National Museum (Proc. U. S. Nat. Mus., XLI, 1912, p. 603).

\section{Diastylis rathkii Krфyer.}

Locality-"Station 48a, Goulbourn point, Bathurst inlet, Northwest Territories, about lat. $67^{\circ} 35^{\prime} \mathrm{N}$., long. $108^{\circ} 40^{\prime} \mathrm{W}$., May, 1916. From stomach of Cottus quadricornis." 1 female.

Remarks.-The partially digeisted specimen is not in a condition to permit accurate determination of specific characters, but from its size (19 mm.) and from the absence of a marked gap between the 2 nd and $3 r d$ legs it may be referred to this widely distributed species rather than to $D$. sulcata.

To the synonymy of this species should, I think, be added Alauna uncinata Baird (in Sutherland's "Journ. Voy. Baffin's Bay", 1852, Vol. II, Appendix, p. cciv, text-fig. 2). The specimen, which was from Assistance bay, Cornwallis island, Barrow strait (about lat. $75^{\circ} \mathrm{N}$., long. $95^{\circ} \mathrm{W}$.) is not to be found in the British Museum collection, but from the figure, it almost certainly belonged to $D$. rathkii.

\section{Diastylis sulcata Calman.}

Locality.-Station 27s. "Collinson point, Alaska, lat. $69^{\circ} 59^{\prime} 06^{\prime \prime} \mathrm{N}$., long. $144^{\circ} 49^{\prime} 57^{\prime \prime}$ W., 3rd October, 1913. About 3 fathoms. Mud with algae." Many specimens.

Remarks.-The females, none of which is ovigerous, agree very closely with the specimens which I described (Proc. U.S. Nat. Mus. XLI, 1912, p. 654) from an Alaskan locality far to the south-west of that now recorded. The adult males, all of which are badly damaged, differ from typical males of $D$. rathkii in the rather more elongated carapace. The ridge crossing the dorsal surface behind the ocular lobe is less marked than in the female and bears no teeth, but the vertical continuation of it on the side of the carapace is strong and serrated and is continued, below the lateral keel of the carapace, as the upper lip of a deep supra-marginal furrow.

In neither sex have I been able to perceive pigment or any distinct evidence of ocular structure on the small ocular lobe. In preserved specimens of $D$. rathkii, however, the eye is no more distinct than it is here, and the use made of this character by Stebbing (Das Tierreich, Cumacea, p. 90) for separating the two species is not justified.

\section{Diastylis sulcata var.}

Localities.-Station 28o. "Collinson Point, Alaska, 8th July 1914. From stomach of Salvelinus malma." Many females (some ovigerous) and young males.

1 Published by permission of the Trusteas of the British Museum. 
Station 27c. "Lagoon-bay at Collinson point, Alaska, "15th September 1913. 0-1 foot of water." 1 adult male.

Remarks.-The females and young males from the first-named locality differ from typical specimens of $D$. sulcata in lacking the furrow from which the species takes its name. While the spiniferous ridge crossing the frontal lobe is well-marked, its vertical continuation on the side of the carapace is indistinct, and there is no horizontal ridge or furrow above the lower margin. The only other differences worthy of mention are that the postero-lateral prolongations of the last thoracic somite are shorter and less acute, and that the telson, instead of being longer than the peduncles of the uropods, is a little shorter.

On the other hand the specimens agree with $D$. sulcata and differ from $D$. rathkii in the less inflated form of the carapace, which is smooth except for the transverse row of spinules on the frontal lobe, and in the greater backward prolongation of the side-plates of the third and fourth free thoracic somites, leading to a marked separation between the second and third pairs of legs. It must be admitted that these differences of facies are hard to define with precision and are unconvincing as a ground for specific separation. Although the specimens appear to me to resemble the types of $D$. sulcata more closely than they do any of the forms of the polymorphic $D$. rathkii with which I have compared them, they justify a strong suspicion that $D$. sulcata may be, at most, only a local race of that species.

The male from lagoon bay, lacking the supra-marginal furrow of the typical males of $D$. sulcata described above, approaches $D$. rathkii even more closely than do the females and it is only recorded here because of its agreement in size with the females found in the same neighbourhood.

\section{Diastylis goodsiri (Bell).}

Locality.-Station 43a. "Off Cockburn point, Dolphin and Union strait, Northwest Territories, about lat. $68^{\circ} 50^{\prime}$ N., long. $115^{\circ}$ W., 13th September, 1915. About 50 fathoms. Mud with pebbles; no algæ." 1 male, 1 female, both immature. "Uniformly white-grey coloured."

Remarks.-The distribution of this conspicuous and well-known species is given in detail by Hansen (Ingolf Malacostraca, IV, 1920, p. 58). The present record extends its known range somewhat to the west but there remains a large gap towards the eastern record of $116^{\circ} \mathrm{E}$. (Stuxberg). Further research may diminish or obliterate this gap, but is appears significant that the species was not found among the rich Alaskan and Bering sea collections of the U.S. National Museum (Calman, Proc. U.S. Nat. Mus., XLI, 1912, p. 662).

\section{Diastylis spinulosa Heller.}

Locality.-Station 43a. "Off Cockburn point, Dolphin and Union Strait, Northwest Territories, about lat. $68^{\circ} 50^{\prime}$ N., long. $115^{\circ}$ W., 13 th September, 1915. About 50 fathoms. Mud with pebbles, no algæ." 1 female (broken).

Remarks. - The specimen is very fragmentary, but, in spite of the presence, on the surviving portions of the carapace, of more numerous spinules than are usually attributed to this species, there can be little doubt as to its identification. The species has not been recorded west of $74^{\circ} 20^{\prime} \mathrm{W}$., or east of $83^{\circ} 8^{\prime} \mathrm{E}$. 


\section{Report of the Canadian Arctic Expedition, 1913-18.}

\section{Volume I: General Introduction, Narrative, Etc.}

Part A: Northern Party, 1913-18.

Part B: Southern Party, 1913-16. By Rudolph Martin Anderson. (In preparation).

\section{Volume II: Mammals and Birds.}

Part A: Mammals. By Rudolph Martin Anderson. (In preparation).

Part B: Birds. By R. M. Anderson and P. A. Taverner. (In preparation).

\section{Volume III: Insects.}

Introduction. By C. Gordon Hewitt. (In press).

Part A: Collembola. By Justus W. Folsom. (Issued).

Part B: Neuropteroid Insects. By Nathan Banks. (Issued).

Part C: Diptera. By Chas. W. Alexander, Harrison G. Dyar, and J. R. Malloch. (Issued).

Part D: Mallophaga and Anoplura. By A. W. Baker, G. F. Ferris, and G. H. F. Nuttall. (Issued).

Part E: Coleoptera. By J. M. Swaine, H. C. Fall, C. W. Leng, and J. D. Sherman, Jr. (Issued).

Part F: Hemiptera. By E. P. Van Duzee. (Issued).

Part G: Hymenoptera and Plant Galls. By Alex. D. MacGillivray, Charles T. Brues, F. W. L. Sladen, and E. Porter Felt. (Issued).

Part H: Spiders, Mites, and Myriapods. By J. H. Emerton, Nathan Banks, and Ralph V. Chamberlin. (Issued).

Part I: Lepidoptera. By Arthur Gibson. (Issued).

Part J: Orthoptera. By E. M. Walker. (Issued).

Part K: General Observations on Insect Life in the Arctic. By Frits Johansen. (In preparation).

\section{Volume IV: Botany.}

Part A. Freshwater Algae and Freshwater Diatoms. By Charles W. Lowe. (In preparation).

Part B. Marine Algae. By F. Collins. (In preparation).

Part C: Fungi. By John Dearness. (In preparation).

Part D: Lichens. By G. K. Merrill. (In preparation).

Part E: Mosses. By R. S. Williams. (In press).

\section{Volume $\nabla$ : Botany.}

Part A: Flowering Plants and Ferns. By James M. Macoun and Theo. Holm: (In preparation).

Part B: General Notes on Arctic Vegetation. By Frits Johansen. (In preparation).

\section{Volume VI: Fishes, Tunicates, Etc.}

Part A: Fishes. By F. Johansen. (In preparation).

Part B: Ascidians, etc. By A, G. Huntsman. (In preparation).

\section{Volume VII: Crustacea.}

Part A: Decapod Crustaceans. By Mary J. Rathbun. (Issued August 18, 1919).

Part B: Schizopod Crustaceans. By Waldo L. Schmitt. (Issued September 22, 1919).

Part C: Cumacea. By W. T. Calman. (In press).

Part D: Isopoda. By Miss P. L. Boone. (In press)

Part E: Amphipoda. By Clarence R. Shoemaker. (Issued September 7, 1920).

Part F: Pycnogonida. Leon J. Cole. (In press).

Part G: Euphyllopoda. By F. Johansen. (In preparation).

Part H: Cladocera. By Chancey Juday. (Issued June 28, 1920).

Part I: Ostracoda. By R. W. Sharpe. (In preparation).

Part J: Freshwater Copepoda. By C. Dwight Marsh. (Issued April 21, 1920).

Part K: Marine Copepoda. By A. Willey. (Issued June 25, 1920).

Part L: Parasitic Copepoda. By Charles B. Wilson. (Issued August 6, 1920).

Part M: Cirripedia. By H. A. Pilsbry. (In preparation).

\section{Volume VII: Mollusks, Echinoderms, Coelenterates, Etc.}

Part A: Mollusks, Recent and Pleistocene. By Wm. H. Dall. (Issued).

Part B: Cephalopoda and Pteropoda. By S. S. Berry and W. F. Clapp. (In preparation).

Part C: Echinoderms. By Austin H. Clark. (Issued).

Part D: Bryozoa. By R. C. Osburn. (In preparation).

Part E: Rotatoria. By $\mathbf{H}$. $\mathbf{K}$. Harring. (In preparation).

Part F: Chaetognatha. By A. G. Huntsman. (In preparation).

Part G: Actinozoa and Alcyonaria. By A. E. Verrill. (In press).

Part H: Medusae and Ctenophora. By H. B. Bigelow. (Issued).

Part I: Hydroids. By McLean Fraser. (Issued).

Part J: Porifera.

Volume IX: Annelids, Parasitic Worms, Protozoans, Ete.

Part A: Oligochaeta. By Frank Smith and Paul S. Welch. (Issued).

Part B: Polychaeta. By Ralph V. Chamberlin. (In press).

Part C: Hirudinea. By J. P. Moore. (In press).

Part D: Gephyrea. By Ralph V. Chamberlin. (Issued).

Part E: Acanthocephala. By H. J. Van Cleave. (Issued).

Part F: Nematoda. By N. A. Cobb. (In preparation).

Part G-H: Trematoda and Cestoda. By A. R. Cooper. (In press).

Part I: Turbellaria. By A. Hassell. (In preparation).

Part J: Gordiacea.

Part K: Nemertini.

Part L: Sporozoa. By J. W. Mavor. (In preparation).

Part M: Foraminifera. By J. A. Cushman. (Issued).

Volume X: Plankton, Hydrography, Tides, Etc.

Part A: Plankton. By Albert Mann. (In preparation).

Part B: Marine Diatoms. By L. W. Bailey. (In preparation).

Part C: Tidal Observations and Results. By W. Bell Dawson. (In press).

Part D: Hydrography. (In preparation). 


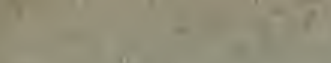

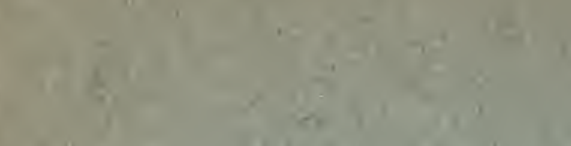

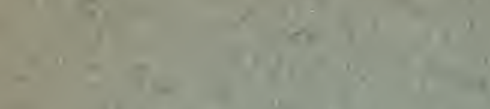

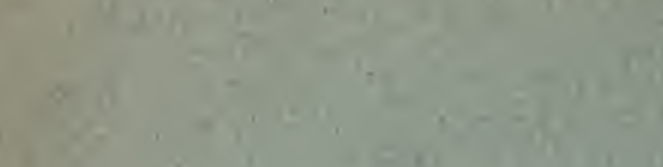

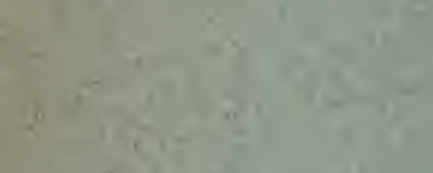

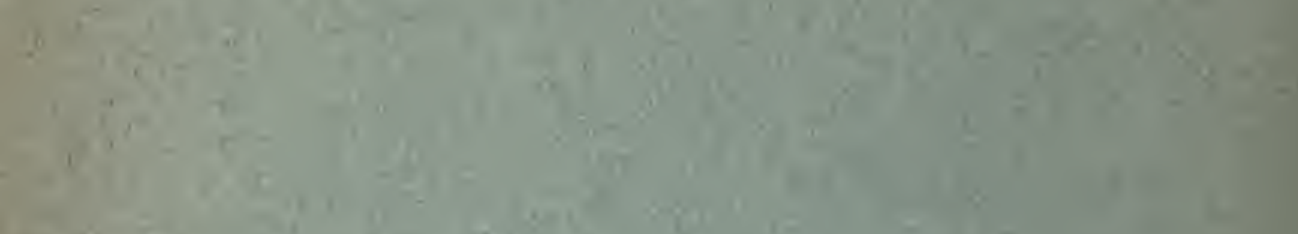

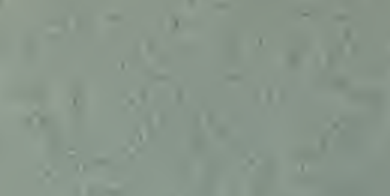

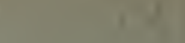

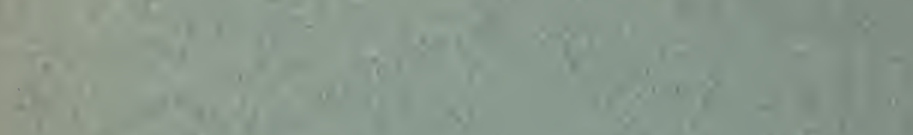

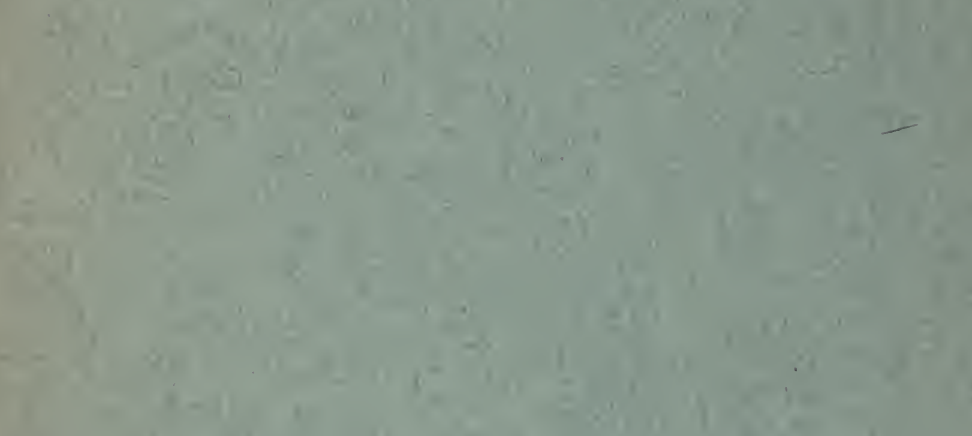

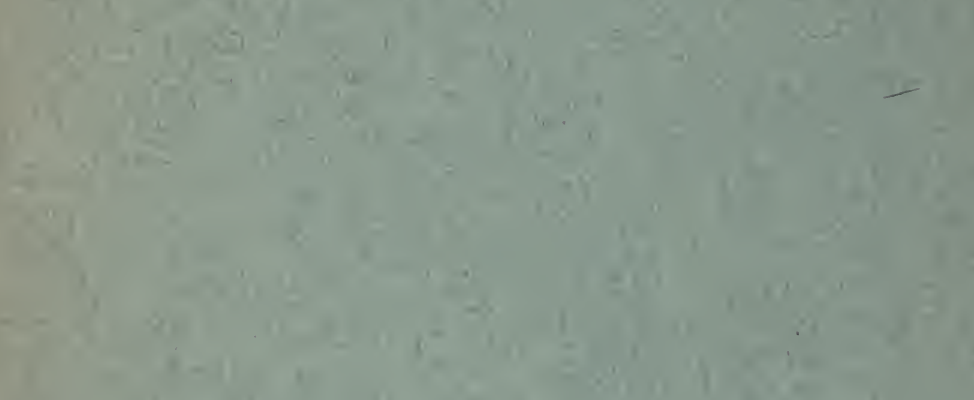

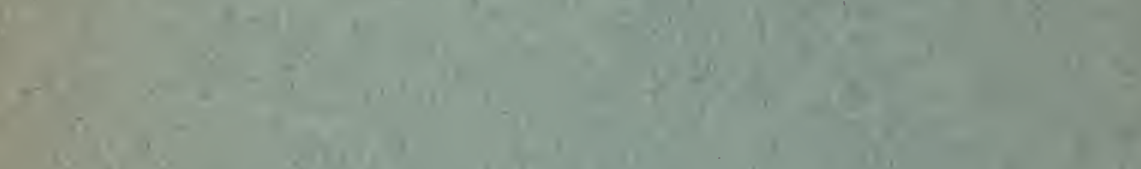

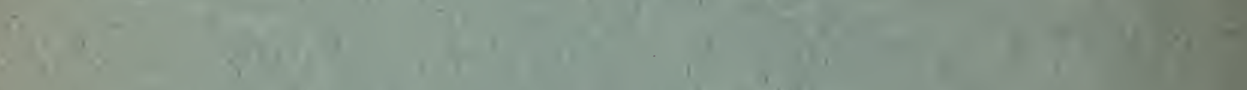

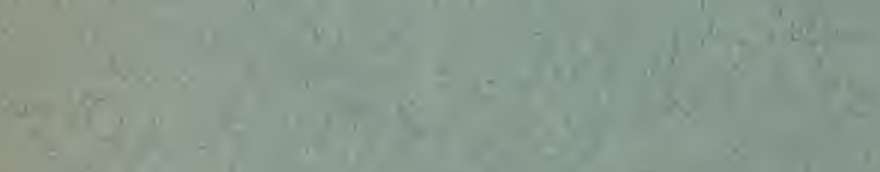

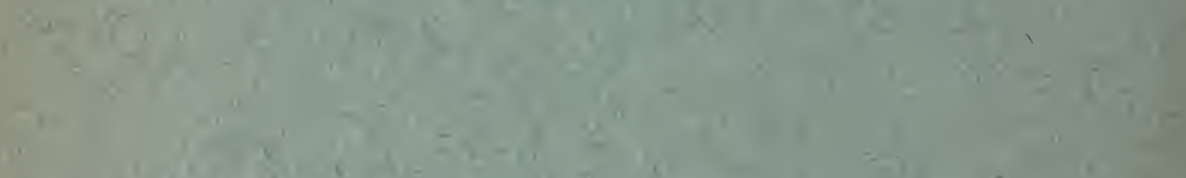

. 